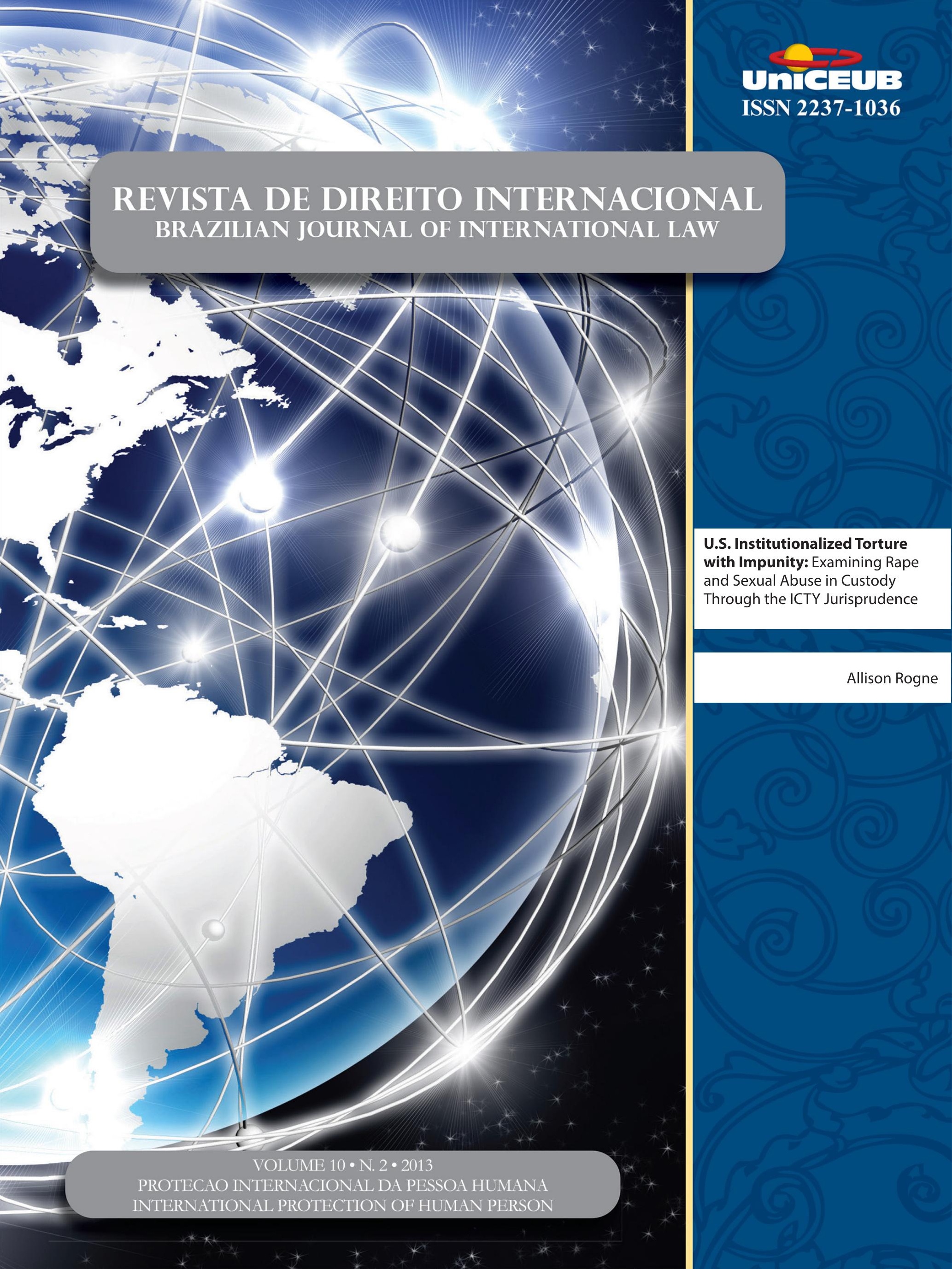




\section{Artigo Especial}

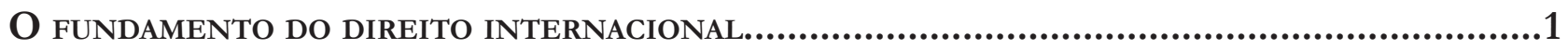
Alfred Verdross

\section{Proteção Internacional dos Direitos Humanos}

INDIGENOUS RIGHTS MOVEMENT: IS THE SAME NEEDED TO PREVENT CONTINUED HUMAN RIGHTS VIOLATIONS OF THE MENTALLY ILL

Liesel LeCates

O Discurso DAS DROGAS CONSTRUído PELO DIREITO INTERNACIONAL

Camila Soares Lippi

O ESTADO DEMOCRÁTICO DE DIREITO LAICO E A "NEUTRALIDADE" ANTE A INTOLERÂNCIA RELIGIOSA

Antonio Baptista Gonçalves

UM DiREITO SEM ESTADO? DiREITOS humanos E A FORMAÇÃo DE UM NOVO QUADRo NORMATIVO GLOBAL .87

Anderson Vichinkeski Teixeira e Rafael Köche

\section{Direito Humanitário}

The U.N. Standard Minimum Rules for the Treatment of Prisoners and North Korea: How North Korea is Violating these Rules with its Operation of the Yodok Concentration CAMP.

Tom Theodore Papain

U.S. Institutionalized Torture with Impunity: Examining Rape and Sexual Abuse in Custody Through the ICTY JurisprudenCE. 126 Allison Rogne 
Abduction, Torture, Interrogation: An Argument Against Extraordinary RendiTION

Kaitlyn E. Tucker

United States and European Union approaches to the death penalty: America SHOULD CONSIDER A NEW PERSPECTIVE 155 Katie R Hill

Tudo DE NOVO NO FRONT: MONUSCO, UMA NOVA ERA NAS PEACEKEEPING OPERATIONS? .169 Priscila Fett

A ADMINISTRAÇÃo DE TERRITÓRIOS OCUPADOS: INDETERMINAÇÃO DAS NORMAS DE DIREITO INTERNACIONAL HUMANITÁRIO?. 184 João Henrique Ribeiro Roriz, Fabia Fernandes Carvalho Veçoso e Lucas da Silva Tasquetto

THE (IN)APPLICABILITY OF THE STATUTE OF REFUGEES TO ENVIRONMENTALLY DISPLACED PERSONS 197 Maria Cláudia da Silva Antunes de Souza e Lucas de Melo Prado

\section{Sistema Interamericano de Direitos Humanos}

A contribuição da Comissão Interamericana de Direitos Humanos para o acesso À jus-

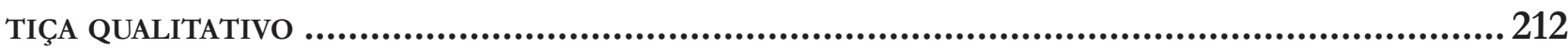
Márcio Antônio de Oliveira Filho, Ana Caroline Portes de Oliveira, Jéssica Galvão Chaves e Warlen Soares Teodoro

A executividade das sentenças da Corte Interamericana de Direitos Humanos no

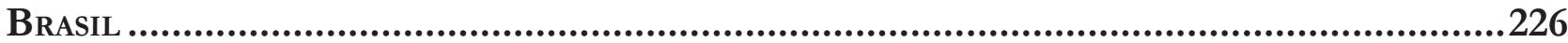

Augusto César Leite de Resende

A efetividade do ativismo jurídico transnacional no Sistema Interamericano de DiREITOS HuMANOS: UMA ANÁLISE A PARTIR DE CASOS CONTRA O BRASIL .................................238 Renata Mantovani de Lima e Lucélia de Sena Alves

O Processo e o Direito Coletivo no Sistema Interamericano de Direitos Humanos: UMA ANÁLISE COM BASE NA JURISPRUDÊNCIA INTERNACIONAL ...........................................250 Laercio Dias Franco Neto e Dafne Fernandez de Bastos 
CORTE INTERAMERICANA DE DIREITOS HUMANOS: OPINIÃo CONSULTIVA 4/84 - A MARGEM DE

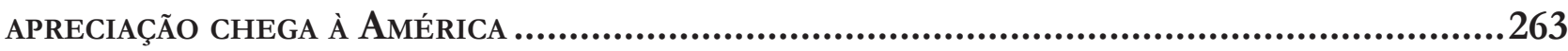

Paloma Morais Corrêa

A "PLENA" LIBERDADE DE EXPRESSÃo E OS DIREITOS HUMANOS: ANÁLISE DA JURISPRUDÊNCIA DA Corte InTeramericana de Direitos Humanos e o Julgamento da ADPF 130 281 Natália Paes Leme Machado

A proteção do meio ambiente no Sistema Interamericano de Direitos Humanos a parTIR DO DIREITO À EDUCAÇÃO.

Augusto César Leite de Resende

Parameters and procedures of the Inter-American System of Human Rights in CHILDREN'S RIGHTS VIOLATION LAWSUITS

Maria Guiomar da Cunha Frota e Pedro Alves Barbosa Neto

Poverty as a Violation of Human Rights: THE CASE OF STREET CHILDREN IN GUATEMALA AND BRAZIL

Paloma Morais Correa

\section{Proteção Internacional dos Direitos Humanos e o Direito Brasileiro}

A LEI N. 11.340/06 E SUAS REPERCuSSõES No CONTRATO INDIVIDUAL DE TRABALHo. Humberto Lima de Lucena Filho e Waldeny Pereira Filho

ORIENTAÇÃo SEXUAL E DISCRIMINAÇão NO AMBIENTE LABORAL

Glaucia Fernanda Oliveira Martins Batalha

NORMAS EDITORIAIS 


\title{
U.S. Institutionalized Torture with Impunity: Examining Rape and Sexual Abuse in Custody Through the ICTY Jurisprudence*
}

Allison Rogne**

\begin{abstract}
This article examines rape and sexual assault within the United State's prison system and posits that it reaches a level of torture with impunity that, when looked at through the lens of international criminal jurisprudence, may indicate that female prisoners do not deserve protection against rape, and may in fact be consider deserving of such treatment. It is a well-established principle, both domestically and internationally, that rape is torture when suffered as part of confinement. It is also well documented, both domestically and internationally, that rape is rampant in U.S. prisons. And it is well established, both domestically and internationally, that those who torture should not do so with impunity, that that impunity is an affront to civilization and the human rights principles to which we all strive. This article examines the situation of women incarcerated in the U.S. and the level to which they experience rape and sexual assault at the hands of correctional staff. The article also walks through the legal structure that instead of aiding these victims in finding justice, in practice inhibits that justice. The article looks to the ICTY jurisprudence to compare the treatment of rape as torture and explores the different treatment by courts of females imprisoned for crimes and those imprisoned in war, noting that women who are labeled as criminal as opposed to captive are, in effect, undeserving of protection. This article submits that government institutionalized torture, where the perpetrators are treated with impunity, is an even greater crime.
\end{abstract}

\section{U.S. InSTITUTIONALIZED TORTURE WITH IMPUNITY: EXAMINING RAPE and Sexual Abuse in Custody Through the ICTY Jurisprudence}

\footnotetext{
"I was given direct orders to come to his office on numerous occasions and on a daily basis. It had gotten to the point where he would approach me on the yard demanding to see me. After coming to his office upon request the sexual assaults started to take place. I was ordered to perform oral sex on him as well as having sex with him right in his office... Upon talking to the Investigator and warden about what had happened... I was placed under investigation for 22 days in solitary confinement."

"He pushed me down on to a mattress and proceeded to pull down my pants and panties... He bit my forearm in three different places, I had bruises on my legs and back where I fought him and tried to turn over, as I was face down. Anyway, I ended up hysterical." 2
}

* Recebido em 02/07/2013 Aprovado em 21/08/2013

** American University Washington College of Law (e.g. "University of California, Berkeley"). Email: ar7420a@student.american.edu
1 Stop Prisoner Rape - Survivor Stories: Geneva Bell. Available at: http://spr.igc.org/en/ survivorstories/genevaoh.html (accessed April 26, 2013).

2 Stop Prisoner Rape - Survivor Stories: Johanna, California. Available at: http://sprigc. org/en/survivorstories/johanna.html (accessed April 26, 2013). 
"In California, the Bureau of Prisons placed women in a men's prison, where guards sexually harassed the women, opened their cells at night, and let male prisoners into the cells to rape them. After a group of women prisoners reported this abuse the white women were transferred while the black women remained in the men's prison for an additional ten days. One of these women was 'beaten, raped and sodomized' by three men who told her 'the attack was in retaliation for her complaint'."'3

"He trampled on my pride and I will never be able to be the woman that I was."

\section{INTRODUCTION}

Above are the stories and words of women who have suffered rape as torture within prisons. Some of these women were confined in the prison camps of the Former Yugoslavia, some were confined in the U.S. not during a war, but in a system that continues to run with government sanction. It is a well-established principle, both domestically and internationally, that rape is torture when suffered as part of confinement. It is also well documented, both domestically and internationally, that rape is rampant in U.S. prisons. And it is well established, both domestically and internationally, that those who torture should not do so with impunity, that that impunity is an affront to civilization and the human rights principles to which we all strive. And yet, in U.S. prisons, shocking numbers of women are systematically raped and sexually abused by those that would rehabilitate them. Female prisoners are victims of vaginal and anal rape; forced oral sex; forced digital penetration; quid pro quo coercion of sex in order to retain privileges or protection; and sexual threats to name a few. ${ }^{5}$ Female prisoners face this kind of abuse daily, all while confined, unable to avoid the abuser, at their constant mercy. This abuse rises to the level of torture, both in the very real effects on these prisoners, and also in legal definition. Torture in itself is a crime. Rape in itself is a crime. But this article submits that government institutionalized torture, where the perpetrators are treated with impunity, is an even greater crime. It sends the signal to perpetrators, victims, and the public, that these

3 Kim Shayo Buchanan, "Impunity: Sexual Abuse in Women's Prisons” 42 Harv. C.R. - C.L. L.Rev. 45, at 65, (2007).

4 Grozdana Ćećez, ICTY testimony, recounting her rape at the Čelebići prison camp. Available at: http://www.icty.org/sid/196

5 Id. crimes will go unpunished, in fact they will be protected through a series of complicated legal barriers, and that these women, these victims, are not even worth protection. In the barriers imposed, both institutional and cultural, the impunity of prison rape indicates that not only are the victims unworthy of protection, but that on some level, whether subconsciously or consciously, our society believes that these women deserve this abuse.

This article examines the situation of women incarcerated in the U.S. and the level to which they experience rape and sexual assault at the hands of correctional staff. To understand that dark reality, the article presents both statistical and anecdotal evidence of the widespread and systematic nature of these instances. This is where the U.S.'s cultural understandings of prison rape emerges in the article as a thread connecting the different sections. Next the article begins to dissect three major categories of law: Domestic Civil Law; Criminal Law; and International Law. These sections present applicable U.S. and international law and then apply international human rights norms as a lens through which to analyze the reality of prisoners in the U.S.

The Domestic Law sections look at the existing U.S. laws through which prisoners can obtain justice. It also will describe different mechanisms as well as barriers to that justice such as the Prison Litigation Reform Act and prosecutorial discretion. The criminal portion focus on the criminal law the ideological and institutional barriers to criminal prosecution against those who rape female prisoners in the U.S. Finally, the Domestic section includes a brief discussion of the Prison Rape Elimination Act (PREA), an analysis of the stated purpose, and real outcomes as seen so far, as well as what these say about the possible change in cultural attitudes regarding prison rape. The International section is an examination of the effect of the $8^{\text {th }}$ Amendment in generating standards and jurisprudence in instances of rape and sexual assault, and how the subsequent laws fall short of international legal standards (introduced in the next section) proscribed by the Convention Against Torture and the International Covenant on Civil and Political Rights, both of which the U.S. is a party. The International portion also contrasts and compares instances in which rape has been found to be torture within the context of mass atrocity and war. While the climate and circumstances differ in many ways, the comparison is helpful to understanding the way in which rape rises to the level of torture, as well as the particular gravity of governments giving license to torture wo- 
men in this way. Specifically, the paper examines some of the leading jurisprudence from the International Tribunal for the Former Yugoslavia. The case deals with multiple counts of rape as torture based on the conditions and crimes committed in detention centers in the region. While the war time conditions and the reasons for confinement are vastly different than the situation of the U.S. prisons, the article argues that if these actions are so quickly accepted as criminal in societal breakdown like that of the Former Yugoslavia, it is all the more proof that the situation in the U.S. is an extreme violation of international standards, allowing the rape of thousands to occur with complete impunity. It can only be concluded that because the victims in the U.S. are labeled as criminal, unlike the counterparts in the Former Yugoslavia targeted for their ethnicity, they deserve to suffer these crimes. ${ }^{6}$

Finally the paper concludes that with the mass amount of regulation, law, jurisprudence, and advocacy, juxtaposed with the continued impunity, it can be concluded that not only are these women seen by both the public and their government as unworthy of protection, but also they are deserving of rape as torture, in addition to their punishment of incarceration. At last the paper makes a recommendation: that the lessons learned from PREA as it gains ground, begin to inform new efforts for reform in prosecution, a natural next step in a trend towards growing recognition that rape as torture cannot be committed with impunity.

\section{THE RAPE OF FEMALE PRISONERS INCARCERA- TED IN THE U.S.}

\subsection{Data}

Like rape in the public sector, prison rape is often unreported and it is therefor difficult to collect data on the rate of incidence. ${ }^{7}$ According to the National Institute of Justice, there have been 25 studies on prison

\footnotetext{
6 While not addressed in this paper, the racial makeup of female prisoners may also contribute to the notion that the women who are raped in prison deserve it. Women of certain racial background have been viewed for many years in our society as impure and therefor unrapeable.

7 National Institute of Justice. Prison Rape. Available at: http:// www.nij.gov/nij/topics/corrections/institutional/prison-rape/welcome.htm
}

rape, each with a different methodology, some focusing on inmate interviews, some on filed reports. Hard data on actual incidence of prison rape nation wide continues to be difficult to gather, let alone data that specifically concerns rape of female inmates by prison staff.

In 2003 the Prison Rape Elimination Act (PREA) passed in the U.S. In producing the Act, Congress set out to determine the situation within U.S. prisons with respect to rape and made the following findings. At the end of 2001 there were 2,100,146 people incarcerated within the U.S. Of them, 1,324,465 were in Federal and State facilities, while 631,240 were housed in county and local jails. ${ }^{8}$ Congress also found, with some difficulty, that an estimate of at least 13\% of U.S. inmates had been sexually assaulted in some form while incarcerated. With this calculation, it was determined that nearly 200,000 inmates had been the victims of prison rape and that the number of those sexually assaulted in the preceding 20 years was over 1,000,000. The report also found that, in keeping with what we know about prison rape culture, inmates who suffer from mental illness and young first-time offenders are at an increased risk of sexual victimization within prison. In particular, juveniles are at 5 times greater risk to be sexually assaulted if kept in an adult facility and that these assaults tend to occur within the first 48 hours of incarceration there. These numbers are mostly estimates because prison rape, not unlike rape outside prison, is largely underreported. Prison rape also increases the number of homicides and violence against both inmates and prison staff. In addition to the troubling statistics concerning the prevalence of prison rape, Congress also found that prison rape effects public safety; that brutalized inmates are more likely to commit crimes upon release. And finally, the report indicated that these high incidents increase costs incurred by Federal, State, and local jurisdictions in administration of their prison systems. The report made clear that prison rape is a human rights concern, as well as public safety concern. These statistics informed the drafting of the PREA. The first reporting period under these standards will be available sometime in 2014 and therefore a picture of the success of the standards in implementation is limited.

Since the passing of the legislation in 2003, the standards have undergone review and change - going into full-scale effect this past August. While the reporting period has not yet begun, the following data is available. As part of PREA, the

$8 \quad$ PREA.pdf doc Sec 2 Findings 
Bureau of Justice Statistics (BJS), under the U.S. Department of Justice, carries out a comprehensive statistical review and analysis of prison rape each year. The Act also requires the Attorney General to submit a report by June $30^{\text {th }}$ of each year in which all 7,600 correctional facilities covered by the Act are ranked according to incidence of prison rape. ${ }^{9}$ In 2012, the BJS came out with the following information. An estimated $9.6 \%$ of former state prisoners reported one or more incidents of sexual victimization while incarcerated. ${ }^{10}$ Approximately $5.3 \%$ of former state prisoners reported an incident involving facility staff. ${ }^{11}$ The BJS estimates that $1.2 \%$ of former prisoners reported they unwilling had sex or sexual contact with facility staff, while $4.6 \%$ reported that they willingly had sex or sexual contact with staff. ${ }^{12}$ The reporting indicated that, following their release from prison, $79 \%$ of those unwillingly sexually victimized by staff felt shame or humiliation, and $72 \%$ felt guilt. ${ }^{13}$ Investigations other than those by BJS have indicated that staff sexual victimization of female inmates is much more prevalent. DOJ investigations into women's prisons in Michigan and Arizona found that nearly all the women interviewed reported some form of sexual aggression by guards. ${ }^{14}$

While it is difficult to gather hard data on the incidence rate nationwide, what is not hard to determine is the effect that prison rape has on the victims. Aside from understanding the widespread incidence of staff-on-prisoner rape, it is important to understand the experience. The experience, better than the statistics, illustrates the crime and human rights violation, and the importance of stopping it. Prisoners who experience rape in confinement at the hands of those who guard them live in an inescapable nightmare. Many prisoners suffer multiple abuses while incarcerated because they have been identified by their abusers as vulnerable. ${ }^{15}$

9 U.S. Department of Justice. PREA Data Collection Activities, 2012. June 2012, NCJ 238640.

10 Id.

11 Id.

$12 I d$. It is important to note that while it is described as willing by the inmate, sexual contact between inmates and guards is an inappropriate abuse of authority and in the majority of states a criminal offense. The power dynamic in custody is seen as making it legally impossible for an inmate to consent to sexual contact with any staff. See M. Dyan McGuire, the Empirical and Legal Realities Surrounding Staff Perpetrated Sexual Abuse of Inmates,Criminal Law Bulletin (2010); Ronald Dobash et al, The Imprisonment of Women (1986); Ashley E. Day, Comment, Cruel and Unusual Punishement of Female Inmates: The Need for Redress Under 42 U.S.C. \$1983, 38 Santa Clara L. Rev. 555 (1998).

13 Id.

14 M. Dyan McGuire.

15 Just Detention International. "Learn the basics about prison
Victims of prison rape are likely to suffer both physically and emotionally, from developing post-traumatic stress disorder (PTSD), depression, drug addiction, to contracting sexually transmitted diseases, in particular HIV/AIDS. ${ }^{16}$ Survivors of prison rape suffer from both immediate and long-term mental health issues. In the short term these can include fear, anxiety, an exaggerated startle response, depression, impaired memory and concentration, rapid mood swings, difficulty sleeping or eating regularly, and an inability to complete regular daily tasks. ${ }^{17}$ Each of these conditions are difficult to deal with when outside a prison but it is important to remember that the victim suffers these conditions while incarcerated, where access to mental health care is significantly less than outside prison. Many women do not receive adequate mental health care following sexual assault in prison and as a result can suffer long term as well. ${ }^{18}$ These long-term mental health concerns include PTSD, depression, addiction, and suicidal ideation. ${ }^{19}$ For victims who are forced to suffer multiple assaults or are under the supervision of their attacker, the risks are greater. They can suffer Complex PTSD which is a severe form caused by prolonged trauma. ${ }^{20}$ And again, all of this is suffered while incarcerated, adding to the difficulties of being in prison and surviving rape, two things that are hard enough on their own, but compound each other.

\section{Domestic Law}

\subsection{How does the U.S. define cruel and unusual punishment? Where is rape situated within that definition?}

The U.S. Constitution provides protection for those incarcerated against cruel and unusual punishment through the $8^{\text {th }}$ Amendment. It reads, "excessive bail shall not be required, nor excessive fines imposed, nor cruel and unusual punishments inflicted." ${ }^{21}$ What cons-

rape." 2013. Available at: http://www.justdetention.org/en/learn_ the_basics.aspx

16 Id.

17 Just Detention International. Mental Health Consequences of Sexual Violence in Detention. February 2009.

18 Id.

19 Id.

20 Id.

21 The amendment applies to those convicted and in custody, while the $5^{\text {th }}$ amendment serves as a similar protection for those in 
titutes cruel and unusual punishment has been litigated before the Supreme Court which has determined that punishments themselves must be barred, defined as the "unnecessary and wanton infliction of pain.".22 Additionally Title 18 of the United States Code (U.S.C.) defines the criminal act of torture as the following:

$$
\begin{aligned}
& \text { (1) "torture" means an act committed by a person } \\
& \text { acting under the color of law specifically intended } \\
& \text { to inflict severe physical or mental pain or suffering } \\
& \text { (other than pain or suffering incidental to lawful } \\
& \text { sanctions) upon another person within his custody } \\
& \text { or physical control; } \\
& \text { (2) "severe mental pain or suffering" means the } \\
& \text { prolonged mental harm caused by or resulting } \\
& \text { from- }
\end{aligned}
$$

(A) the intentional infliction or threatened infliction of severe physical pain or suffering;

(B) the administration or application, or threatened administration or application, of mind-altering substances or other procedures calculated to disrupt profoundly the senses or the personality;

(C) the threat of imminent death; or

(D) the threat that another person will imminently be subjected to death, severe physical pain or suffering, or the administration or application of mind-altering substances or other procedures calculated to disrupt profoundly the senses or personality; and

(3) "United States" means the several States of the United States, the District of Columbia

The $8^{\text {th }}$ Amendment not only protects prisoners from direct actions by guards, but also from other prisoners. ${ }^{23}$ In order to prove that a rape is in violation of the $8^{\text {th }}$ Amendment, the complainant must prove deliberate indifference on the part of prison officials. ${ }^{24}$ This is a high burden of proof and a subjective one. An $8^{\text {th }}$ Amendment violation is not against the actual perpetrator of the rape, but against the prison and State for essentially ignoring with deliberate indifference the harm that the prisoner victim suffered.

\subsection{Mechanisms: Civil Rights of Institutionalized Persons Act and Section 1983}

There are two main mechanisms of justice for victims of prison rape in the U.S., the first is criminal prose-

pretrial custody. For the purposes of this article, the focus will be on the convicted and incarcerated, not the latter.

22 Whitley v. Albers, 475 U.S. 312, 319 (1986).

23 See Hudson v. Palmer, 468 U.S. 517 (1984).

24 See Farmer v. Brennan, 511 U.S. 825 (1994). cution by the DOJ through Title 18 of the U.S.C. This is addressed in a later section. The second is civil liability under the Civil Rights of Institutionalized Persons Act (CRIPA).

Through CIRPA, the DOJ is able to file suits against the state for abuses within their facilities. These are again separate from private actions by prisoners themselves. The DOJ will compile information from various sources including but not limited to prisoners, attorneys, and prison staff. Based on that information the DOJ will proceed with a suit. In order to do so, the DOJ must have reasonable cause to believe that an institution is subjecting its prisoners to conditions that violate the $8^{\text {th }}$ Amendment. The DOJ will investigate the prison based on the information from those sources, with the facility on notice. The DOJ will interview those housed in the facility, tour it, and review any records of misconduct. The DOJ will still not file a suit at this point. They next will report their findings to the facility and then after a forty-nine-day period file the suit. ${ }^{25}$ These suits are often resolved in negotiations and are not remedies for the prisoner victims themselves.

Prisoners are able to file private suits against the facility for the individual acts of sexual assault that they experience while incarcerated, but these suits are separate from the actions above. These suits are most often brought under Section 1983 of Title 42 (Civil action for deprivation of rights) U.S.C. which provides "every person who, under color of any statute, ordinance, regulation, custom... subjects, or causes to be subjected, any citizen of the United States or other person within the jurisdiction thereof to the deprivation of any rights, privileges, or immunities secured by the Constitution and laws, shall be liable to the party injured in an action at law, suit in equity, or other proper proceeding for redress..." While prisoners have this option available, it is not often exercised because of the limited access prisoners have to legal representation while incarcerated - another barrier to remedy for sexual assault in prison. Civil remedies to prison rape relief are limited and seldom used, in comparison to the projected number of rapes that occur.

\subsection{Barriers: Prison Litigation Reform Act}

The Prison Litigation Reform Act (PLRA), passed in 1995, was an attempt by Congress to reduce

25 No Escape 
the amount of frivolous lawsuits brought by inmates against the State. ${ }^{26}$ The lawmakers themselves indicated a belief that those incarcerated were still deserving of basic human rights, noting specifically a right not to be tortured. However they were concerned by suits that were frivolous and possibly retaliatory, efforts to waste time and money, for things such as "insufficient locker space." ${ }^{27}$ The result, however, has been another significant barrier to relief for those who do suffer significantly, particularly rape victims. The PRLA states "No Federal civil action my be brought by a prisoner confined in a jail, prison, or other correctional facility, for mental or emotional injury suffered while in custody without a prior showing of physical injury." 28 The issue arises with the prior physical injury requirement because courts have difficulty finding that rape is a per se physical injury, and it seems have thus far treated the issue on a case-by-case basis. While in several cases of male on male prison rape the court has found that rape is a "common sense" injury, ${ }^{29}$ the issue becomes more complicated when the victim is a female.

This complication seems to arise from the general perception that female inmates are non-virtuous and therefore "unrapeable." 30 Female prisoners who are approached by guards demanding sexual acts are often not physically harmed in the way that male prison rape victims are. This is often because a female prisoner will "consent" so as to avoid actual physical harm or retaliation by the guard or staff member. ${ }^{31}$ It is because of this type of sexual exchange that the majority of states ${ }^{32}$ have made it a crime for staff and inmates to have sexual contact, determining that those in custody do not have the capacity to consent. Nevertheless, while it is legally an act of sexual assault or rape, there is no obvious physical injury as required by PRLA, as counter intuitive as that may seem. And therefor the civil remedies that should be available to women who chose to come forward, are significantly diminished by the PLRA. While sexual assault and rape always include some force, whe-

26 Deborah M. Golden, "Its Not all In My Head: The Harm of Rape and the Prison Litigation Reform Act" 11 Cardoo Women's L.J. 37 at 44(2004).

27 Id.

2842 U.S.C. $\$ 1997 \mathrm{e}(\mathrm{e})$.

29 Golden at 46.

30 Id.

31 Kim Shayo Buchanan, "Impunity: Sexual Abuse in Women's Prisons" 42 Harv. C.R. - C.L. L.Rev. 45, at 56, (2007).

32 Sarah K. Wake, "Not Part of the Penelty: the Prison Rape Elimination Act of 2003" 32 J. Legis. 220 (2006). re that force is intimidation or fear there may be no sign of physical injury. What makes this aspect of the PRLA such a conundrum is the "common sense" standard in Liner v. Goord referenced above. Any form of sexual assault or rape, even one committed only through a threat of force, is still a physical act. It is one of the oldest recognized forms of physical violence because it is so personal an invasion. ${ }^{33}$ It seems that even absent an outright showing of physical injury in the manner of bruises or cuts, anything deemed rape, as are sexual acts between a prisoner and staff member, should automatically constitute a physical injury. The effect of PRLA, while certainly not the one it seems lawmakers intended, further indicates that female prisoners who are victims of rape are somehow less deserving of remedy and justice, and possibly deserving of that particular torture.

\subsection{Criminal Prosecution}

As difficult as civil remedies for prison rape are, criminal prosecution of a prison official, is exponentially more so. It is not surprising the extreme difficulty to criminally prosecute prison rape, when you consider the difficulty in rape prosecutions involving free citizens. The prison culture, the prison system, and the criminal justice system, as well as the politics of prosecution, all seem to work against this mechanism. Consider first the barriers to bringing charges. Oftentimes women who suffer rape outside of prison are reluctant to come forward because of shame and fear of reliving the experience. ${ }^{34}$ Women in prison have those same mental blocks to telling their story to the police, preparing for a trial, and confronting a rapist in court. On top of that, they are often forced to remain in the custody of their rapists and are aware that coming forward to file a complaint may result in retaliation by either their rapists or other staff. ${ }^{35}$ In the event, however, that a woman does overcome those fears and reports her claim, the issue of prosecutorial discretion will now come into play.

Data collected by the National Institute of Corrections Project on Addressing Prison Rape at the Washington College of Law revealed important findings regarding criminal prosecution of prison rape. The study identified three main reasons why prosecutors are reluctant to take these cases: (1) they are rarely high pro-

\footnotetext{
33 See generally Golden.

34 Buchanan at 65.

35 Id.
} 
file or high value cases; (2) they are difficult to prosecute and high-risk cases; and (3) some prosecutors may consider assault a part of the penalty associated with conviction. ${ }^{36}$ Regarding the first issue identified, prosecutors are elected officials, and their subordinates prioritize cases based on the platform and priorities of the elected prosecutor. In order to be elected, those priorities must reflect those of the community, and therefore it may be safe to say, based on the low incidence of criminal prosecution for prison rape, that communities do not prioritize the rights of prisoners. Prosecuting a case of prison rape may weaken the position of the prosecutor in the community, possibly making the office appear soft on crime, ${ }^{37}$ the kiss of death for politicians everywhere. As to the second deterrent, rape cases are often difficult to prosecute regardless of where they occur. In prison rape cases, all of the standard difficulties in prosecuting rape exist, with the additional difficulties that they are presented by an unsympathetic victim. Juries often find inmates to be unbelievable as witnesses who may be biased against the staff - possibly vindictive. ${ }^{38}$ In addition to unsympathetic victims and witnesses, the case is often difficult to build based on delayed reporting, usually a lack of physical evidence, poor investigation by the facility, and conflicting testimony. ${ }^{39}$ Prosecutors who took part in the study indicated that without corroborative evidence, a prison rape case may be virtually untriable. ${ }^{40}$ That type of evidence is difficult to come by based on prison culture, which often includes a code of silence. ${ }^{41}$ Finally, some prosecutors see their role as ensuring that criminals receive hard sentences. ${ }^{42}$ Often times great stock is placed in the length of sentence a prosecutor is able to obtain for a conviction, and it is suggested that some, though probably a minority, believe that physical abuse in prison is in fact part of that punishment. ${ }^{43}$ While the study seems to indicate that this is in a minority of cases, the low priority given to prison rape prosecution, certainly when the public opinion factor is considered, may indicate that there is a

36 Brenda V. Smith, "Prosecuting Sexual Violence in Correctional Settings: Examining Prosecutors' Perceptions" Washington College of Law Research Paper No. 2008-50.

37 Mark Hansen, "Hunting Rapists Behind Bars"95 - May A.B.A. J. 17 (2009).

38 Id.

39 Id.

40 Id.

41 Id.

42 Id.

43 Smith. belief that these prisoners are less deserving of protections available to free citizens.

\subsection{Prison Rape Elimination Act}

In 2003 the Prison Rape Elimination Act (PREA) was signed into force. It's nine purposes are to: (1) establish a zero-tolerance standard for the occurrence of prison rape in the United States; (2) make the prevention of prison rape a top priority within each of the correctional facility; (3) develop and implement national standards that will enable authorities to detect, prevent, reduce, and punish prison rape; (4) increase available data and information regarding the incidence of prison rape, thereby improving the management and administration of correctional facilities; (5) promulgate standard definitions used in collecting data on the occurrence of prison rape; (6) increase the accountability of prison officials who fail to detect, prevent, reduce, and punish prison rape; (7) protect the Eight Amendment rights of all prisoners in the corrections system; (8) increase the efficiency of federal expenditures; and (9) reduce the effects of prison rape on interstate commerce. ${ }^{44}$

While PREA is not itself a mechanism for relief, it is important for the role that it may play in moving away from impunity. In fact PREA does not create any cause of action whatsoever. It is an act that provides guidelines and regulations for the prison facilities themselves, aimed at reducing the prevalence of prison rape. It does not provide relief to victims through either civil or criminal penalties. It does, however, create an incentive for facilities to reduce instances of prison rape as well as require better data collection regarding those instances. As of this point it is still unclear what the effect of PREA will be, however there is praise and criticism from both sides for the effort. While critics believe it is a superficial step only mandating studies that will prove what we already know, namely that prison rape is a problem. ${ }^{45}$ The proponents believe that it is an acknowledgement of that problem and a step in the direction of ending it. For PREA to be successful, the standards it creates will need to be enforced. Hopefully the act itself may be a harbinger of stronger efforts to come.
$44 \quad 42$ U.S.C. $\$ \$ 15601-15609$.

45 See generally Wake. 


\section{International LaW}

\subsection{International Covenant on Civil and Political Rights}

The International Covenant on Civil and Political Rights (ICCPR) applies to persons deprived of liberties, meaning that the rights set out in the covenant, to which the U.S. is a party, are rights to which prisoners are also entitled. The relevant rights are the following:

Article 7 No one shall be subjected to torture
or to cruel, inhuman or degrading treatment or
punishment. In particular, no one shall be subjected
without his free consent to medical or scientific
experimentation.

Art. 10.1 All persons deprived of their liberty shall be treated with humanity and with respect for the inherent dignity of the human person.

Art. 10.2.b Accused juvenile persons shall be separated from adults and brought as speedily as possible for adjudication.

The main concern with these conventions is that they lack a mechanism for enforcement. This is the over arching issue with much of international law. The gentle balance between accountability and sovereignty in international law is often too delicate and actually unbalanced in favor of sovereignty. The obvious problem being that to function it relies on preserving sovereignty of State parties in order to maintain their support. As a result there is no real mechanism for enforcement while there may be many clear violations. In the case of U.S. prison rape, there are violations of the above sections occurring regularly, however without the enforcement mechanisms, they go largely unadjudicated. The regional human rights bodies are courts of last resort, and while the U.S. is a member of the Inter-American Court of Human Rights, the court's decisions amount to value judgments and advisory opinions that can really only result in shaming the U.S. prison system. Unfortunately, shaming to promote change requires a large platform which the IACHR simply does not have. Without any effective enforcement mechanism, the international conventions become merely guidelines and a standard against which to hold the U.S. if only demonstratively.

\subsection{The Convention Against Torture}

The United Nations Convention Against Torture and Other Cruel, Inhuman or Degrading Treatment or
Punishment, Article 1:

1. For the purpose of this Declaration, torture means any act by which severe pain or suffering, whether physical or mental, is intentionally inflicted by or at the instigation of a public official on a person for such purposes as obtaining from him or a third person information or confession, punishing him for an act he has committed or is suspected of having committed, or intimidating him or other persons. It does not include pain or suffering arising only from, inherent in or incidental to, lawful sanctions to the extent consistent with the Standard Minimum Rules for the Treatment of Prisoners.

2. Torture constitutes an aggravated and deliberate form of cruel, inhuman or degrading treatment or punishment.

\subsubsection{International use of the Convention Against Torture: Establishing Rape as Torture}

Internationally accepted definitions of torture, including rape as torture, continue to evolve with new jurisprudence from the international tribunals as well as various regional human rights courts. To find a definition of rape as torture requires looking to both the Convention Against Torture (CAT) and its applications in this jurisprudence. The CAT, to which the U.S. is a party, broadly defines torture as, "any act by which severe pain or suffering, whether physical or mental, is intentionally inflicted on a person for such purposes as obtaining from him or a third person information or a confession, punishing him...or intimidating or coercing him or a third person, or for any reason based on discrimination of any kind...inflicted by or at the instigation of ... or consent... of a public official...in an official capacity." 46

The concept of rape as torture is a growing one. The notion that rape can be used to torture has grown out of the jurisprudence of the ad hoc tribunals, the International Criminal Tribunals for the former Yugoslavia and Rwanda (ICTY and ICTR respectively). These conflicts were not only characterized by their bloody ethnic tensions, but by the many instances of sex and gender based crimes, particularly the use of rape to torture. There is no internationally accepted legal definition of rape, however the ad hoc tribunals both use a similar definition: "forcible sexual penetration of a

46 Article 1, Convention Against Torture and Other Cruel, Inhuman or Degrading Treatment or Punishment, G.A. res. 39/46, U.N. June 26, 1987. 
person, or forcing a person to sexually penetrate another... [which] includes penetration, however slight, of the vagina, anus or oral cavity, by the penis...not limited to the penis." ${ }^{27}$ Together, the Chambers of both ad hoc tribunals have taken these definitions to find that rape can and has been be used as torture within the conflicts under their jurisdiction. These have constituted groundbreaking decisions, affecting international criminal law, international human rights law, women's rights and many other spheres that confront and combat rape and torture. The jurisprudence of the ad hoc tribunals infor$\mathrm{ms}$ the decisions of the other international courts - the Special Court for Sierra Leone, Special Tribunal for Lebanon, Extraordinary Chambers in the Courts of Cambodia, and the International Criminal Court. While this jurisprudence is not controlling in the U.S., the trend towards prosecuting rape as torture at the international level should spur action within the U.S. to do the same in the many instances of prison rape. At the very least it provides guidance and a platform for those who would seek criminal justice in these instances.

\subsubsection{U.S. reservations to the CAT: what is their affect on prisoners?}

In its ratification of the Convention Against Torture, the U.S. made the following reservation:

The Senate's advice and consent is subject to the following reservations:

(1) That the United States considers itself bound by the obligation under Article 16 to prevent "cruel, inhuman or degrading treatment or punishment," only insofar as the term "cruel, inhuman or degrading treatment or punishment" means the cruel, unusual and inhumane treatment or punishment prohibited by the Fifth, Eighth, and/ or Fourteenth Amendments to the Constitution of the United States. ${ }^{48}$

This reservation effectively alters the definition of torture binding the U.S. under international law, rejecting the broader definition in CAT and adopting the definition within the U.S. Constitution and jurisprudence. In addition to the reservation, there is the Optional Protocol to CAT, not signed by the U.S., which specifically calls for oversight in prisons, allowing for international and national monitoring. As far as CAT is concerned, the U.S. has diminished the ability of prisoners who suffer rape at the hands of the state to site CAT in a quest for relief. It is essentially the same as the violation of the $8^{\text {th }}$ Amendment and carries no enforceable cause of action. However, it should be noted by the Committee Against Torture that many instances of prison rape do fall within the CAT definition of torture. In 2006, the U.S. submitted a report produced by the BJS in accordance with PREA to the Committee Against Torture as part of their reporting under CAT. According to that report, in 2005 there were 2,042 allegations of staff sexual misconduct. ${ }^{49}$ Of those incidents, correctional staff found only 254 to be substantiated. ${ }^{50}$ Of that small number that were substantiated, $82 \%$ of the staff involved were reassigned. ${ }^{51}$ That indicates that a very small number of staff members who have been accused of sexual misconduct have actually been removed from the facility, meaning that the overwhelming majority of prisoners who accused staff of misconduct would likely still be in the hands of the perpetrator.

\section{INTERNATIONAL INCIDENTS AND JURISPRUDENCE}

There have been several instances at the international level where individuals have been prosecuted and found guilty of the crime of rape as torture. While these situations are unique and quite different from those in which women prisoners in the U.S. find themselves victims, there are similarities. And it is perhaps the differences that make them so interesting as a way to view the lack of prosecution in the U.S. This paper hypothesizes that the international acknowledgment of rape as torture and the condemnation of it in situations of war, when compared with the criminal impunity of rape as torture in the U.S., suggests that on some level the women in the U.S. context are believed to be almost deserving of their torture. One of the key differences between the victims in the international cases that will be discussed, and the victims in the U.S. is that the former have not, prior to their torture, been found guilty of any crime.
47 The Prosecutor and Gagovic et.al, Initial Indictment, Case no.: IT96-23, ๆ4.8, International Criminal Tribunal for the former Yugoslavia.

48 UMN Human Rights Library
49 Bureau of Justice Statistic "Sexual Violence Reported by Correctional Authorities, 2005, U.S. DOJ July 2006.

$50 \quad$ Id.

$51 \quad I d$. 
Some background is necessary to understand the cases discussed herein." ${ }^{52}$ The ICTY was established by the UN following the wars in the Balkans in the early to mid 90s. It was established in order to prosecute those most responsible for the war crimes, crimes against humanity, genocide, and grave breaches of the Geneva Conventions, that occurred in the region. ${ }^{53}$ The conflict in the former Yugoslavia, particularly Bosnian and Herzegovina, was marked with sexual violence including many instances of rape as torture, new to the category of torture as previously prosecuted. One of the leading examples of rape as torture took place in the city and municipality of Foča. The ICTY convicted several leaders based on their involvement in the rape as torture of several women in detention centers in the

52 In order to understand the particular crimes charged and convicted, as well as the context that makes these convictions unique when compared to the U.S. and its prison rape situation, a bit of historical background is helpful. In the early 1990s, the Socialist Federal Republic of Yugoslavia (SFRY) was comprised of six republics: Bosnia and Herzegovina, Croatia, Macedonia, Montenegro, Serbia, and Slovenia; and the regions of Kosovo and Vojvodina were considered autonomous provinces within Serbia. The SFRY was made up of several ethnic and religious groups, the majority religions being Orthodox Christians, Catholics, and Muslims. The history of the region, until this point, had been marked with different periods of unrest, often motivated by ethnic or religious tensions, dating back to at least 1389, and the Battle of Kosovo. Prior to the conflicts of the early 1990s, the regions most recent ethnic conflicts had coincided with World War II and included the genocide of the Armenian population of the region, perpetrated by the Turkish leadership. Coinciding with the collapse of the Soviet Union and a resurgence of nationalism, the SFRY underwent a period of political and economic crisis that included the weakening of the central government as nationalist sentiments grew in the different republics. The nationalism sparked calls for independence as well as an imbalance of powers between the different republics, eroding what had been a carefully crafted common Yugoslav identity, increasing age old fear and mistrust among the different ethnic and religious groups. The break up of the SFRY began in 1991. In 1992, conflict began in Bosnia and Herzegovina. It had a very diverse ethnic population, the majority of the makeup being about 43 percent Bosnian Muslims, 33 percent Bosnian Serbs, and 17 percent Bosnian Croats. With overwhelming military superiority the JNA and Serbian armies quickly controlled over 60 percent of the country and the Bosnian Croats rejected the Bosnian government and declared their own republic, backed by Croatia. Around 100,00 people were killed and over two million were forced to flee their homes between April 1992 and November 1995. The campaign to rid Bosnian and Herzegovina of its non-Serb populations was systematic and included the detention, murder, torture and rape of the civilian population as well as massacres of non-Serb men and boys and the expulsion of women and children.

53 Statute of the International Criminal Tribunal for the Former Yugoslavia, Arts. 2-5, entered into force May 25, 1993, UN Resolution 827. region. The case Prosecutor v. Kunarac et al54 deals with crimes committed in the takeover and occupation of Foča, a city and municipality located southeast of Sarajevo, bordering Serbia and Montenegro. ${ }^{55}$ One of the main focuses of the campaign to expel the non-Serb civilians was the targeting of women, using terror to expel them from the region. Women were taken to the various detention centers where Bosnian Serb forces used rape to control them, and also to pleasure and reward. ${ }^{56}$ In addition, several women were detained in homes that functioned as brothels operated by and for groups of soldiers. ${ }^{57}$ The following details the experiences of the women in each of the locations for which leaders of the Bosnian Serb forces were charged with crimes.

\subsection{The Prosecutor v. Kunarac et al}

The Trial Chamber in Kunarac et al adopted the following definition of torture based on the CAT as well as their jurisprudence and that of the ICTR:

(i) The infliction, by act or omission, of severe pain or suffering, whether physical or mental.

(ii) The act or omission must be intentional.

(iii) The act or omission must aim at obtaining information or a confession, or at punishing, intimidating or coercing the victim or a third person, or at discriminating, on any ground, against the victim or a third person. ${ }^{58}$

Note that unlike the U.S. definition of torture found in the U.S.C., the ICTY employs a definition that requires that the infliction of pain or suffering be for a purpose: obtaining information, confession, for punishment, intimidation, coercion, or discrimination. The U.S. definition only requires that the pain or suffering

54 The Prosecutor v. Kunarac et. al. IT-96-23-T \& IT-96-23/1-T ICTY. Kunarac et al was the first case by the ICTY to find convictions of rape as a crime against humanity. The accused: Dragoljub Kunarac, Radomir Kovač, Zoran Vuković.

55 On 7 April 1992, the first military actions in the town of Foca began and the takeover was complete within ten days, while the surrounding villages were under siege until mid July. With the takeover, began the arrests of Muslim and Croat civilians, separating the men from the women, unlawfully confining thousands in detention centers such as Buk Bijela, Foca High School and Partizan Sports Hall. 56 "Foca" IT-96-23 and 23/1 Kunarac, Kovac \& Vukovic, Case Information Sheet, ICTY.

57 The Prosecutor and Gagovic et.al, Initial Indictment, Case no.: IT-96-23, .9ๆ 1.4, 1.5., International Criminal Tribunal for the former Yugoslavia.

58 Prosecutor v. Kunarac et al, Trial Chamber Judgment, IT-9623-T \& IT-96-23/1-T, February 22,2001, ICTY at 497. 
be intentional and severe, and inflicted on someone under the control of the person acting under the color of law. The required element that the individual acting in official capacity have some purpose behind the infliction of the pain and suffering is litigated in instances of rape at the ICTY when the accused claims that the only purpose was sexual satisfaction. However, this distinction does not negate the similarities between the situations that will be outlined in the subsequent sections on ICTY jurisprudence.

Regarding the element of severe pain or suffering, either physical or mental, the ICTY, unlike the U.S. has found that rape is always a means of infliction of severe pain or suffering, either mental or physical, and therefore only seeks to find whether the instances charged involved rape. ${ }^{59}$ The Appeals Chamber in Kunarac states "Generally speaking, some acts establish per se the suffering of those upon whom they were inflicted. Rape is obviously such an act. The Trial Chamber could only conclude that such suffering occurred even without a medical certificate. Sexual violence necessarily gives rise to severe pain or suffering, whether physical or mental, and in this way justifies its characterization as an act of torture." ${ }^{90}$ This departs from the instances described in the prior section on the PLRA. It should be recalled that there is minimal U.S. jurisprudence, and none that is controlling, that suggests that rape itself is a per se cause of pain or suffering. Having determined that rape is always an infliction of severe pain and suffering, the ICTY sought in Kunarac to determine whether the instances charged rose to the level of rape, and if that rape was committed for one of the defined purposes constituting torture.

\subsubsection{Foča High School}

In Kunarac, counts 13-28, for crimes against humanity, violations of the laws and customs of war, and grave breaches of the Geneva Conventions, include rape and torture as the underlying acts, and occurred at the detention center of Foča High School. During the occupation of Foča, the High School functioned as a barracks for Serb soldiers as well as a detention facility for Muslim women, children and the elderly between July 3 and July 13, 1992. ${ }^{61}$

59 Prosecutor v. Kunarac et al Appeals Chamber Judgment, IT96-23-T \& IT-96-23/1-T, June 12, 2002, ICTY at $\$ 150$.

$60 \quad I d$.

61 Gagovic. ๆף 6.1, 6.2.
Every evening at the detention center, women were sexually assaulted and gang- raped by Serb soldiers. The solders threatened to kill the women or their children if they resisted the sexual assaults. Those who did resist were often severally beaten. ${ }^{62}$ The health, both physical and psychological, of these female detainees was seriously compromised. Many suffered from exhaustion, gynecological issues, depression and thoughts of suicide.63 Women were often beaten and raped at gunpoint by soldiers, usually several women in the same room at the same time. In addition to rapes within the detention center, soldiers often took women to the nearby hotel that served as a military headquarters, where they were repeatedly raped. These rapes included vaginal and anal penetration and fellatio. ${ }^{64}$ When women tried to resist being taken for the purpose of rape, they were threatened with death, beatings or mass rape by soldiers on the front lines. ${ }^{65}$ These rapes were not committed as a means of gathering information, or for punishment, they were committed because the women were held in captivity, were accessible, and the soldiers had power over them.

\subsubsection{Partizan Sports Hall}

Counts 36-55 of the initial indictment charge the accused with crimes against humanity, violations of the laws and customs of war, and grave breaches of the Geneva Conventions based on incidents of rape as torture at the Partizan Sports Hall. There, Serb forces held several female victims in detention who suffered repeated rapes at the hands of their captors. Women were kept at Partizan and taken daily to apartments and houses nearby to be sexually assaulted and raped by soldiers. ${ }^{66}$ From around July 13 to August 2,1992, women were detained and raped nearly ever night. The rapes included vaginal and anal penetration and fellatio. ${ }^{67}$ Several of these women, including FWS- $87^{68}$ were raped multiple times while detained at Partizan. On one occasion, FWS-87 was gang-raped by four men. She became suicidal while

\begin{tabular}{|c|c|}
\hline 62 & Id. 6.4 . \\
\hline 63 & 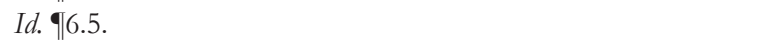 \\
\hline 64 & $I d . \rrbracket \mid 6.6-6.8$ \\
\hline 65 & Id. $\mid 6.11$ \\
\hline 66 & $I d .99 .1$ \\
\hline 67 & $I d$ \\
\hline 68 & At the ICTY, some witnesses and victims are assigned an alias \\
\hline
\end{tabular}


detained at Partizan. ${ }^{69}$ In order to get the detained women to submit to sexual acts, the soldiers threatened the lives of other detainees and made physical threats against the individual women. ${ }^{70}$ Similar to the instances described at Foča High School, the indictment does not indicate any information gathering or interrogational purpose for these rapes.

\subsubsection{Karaman's House}

The final relevant counts, 56-59, of the indictment concern the acts committed by the accused at Karaman's House, a home owned by a Muslim man who lived in Germany. The house was near Partizan and operated as a brothel for the Serb forces. Unlike the detention centers, the living conditions of the brothel were less inhumane. The women had sufficient food and were able to lock their doors against unauthorized men. However, the women who lived in Karaman's House were also subjected to multiple rapes and sexual assaults. ${ }^{71}$ The women lived in constant fear of their lives and several became suicidal. ${ }^{72}$ Like Partizan and Foča High School, there was no interrogation or gathering of information, the women were detained and subjected to rape at the pleasure of their captors.

\subsubsection{Kunarac et al findings regarding rape as tor- ture and how they can inform U.S. proceedings}

In this case before the ICTY, the Trial Chamber found the accused guilty of rape as torture, the first ICTY finding of guilt for rape as a crime against humanity, advancing jurisprudence internationally and giving greater foundation for other instances of rape as torture. While the cases before the ICTY are significantly more complicated than any case that might be brought in the U.S. concerning rape as torture in a prison facility, the findings by the ICTY can provide guidance. ${ }^{73}$ In spi-

\footnotetext{
69 Id. $999.6-9.9$.

$70 \quad$ Id. $\Phi 9.14$.

71 Id. $\uparrow \uparrow 10.2-10.5$.

72 Id. $\uparrow \uparrow 10.6,10.7$.
}

73 The author acknowledges that the cases before the ICTY concern a complex period marked by war, bloody ethnic tension, and political power struggles, unlike any instance of rape as torture within a U.S. prison facility. The article does not attempt to equate the overarching situations or suggest that they are in any way similar. The focus is on the jurisprudence available to courts that wish to pursue charges of rape as torture, as well as the actual instances, their effect on the women, and the similarities that suggest that te of the vast differences, there are significant similarities in the instances before the tribunal and the findings regarding those instances provide jurisprudence for any future U.S. case, or other cases for that matter. The similarities suggest that, regardless of the context in which women are placed in confinement, if they suffer rape or sexual assault at the hands of those who detain them, it must be seen as torture.

In their determination of guilt, the Trial Chamber dealt with issues that mirror those that a U.S. court would face. In one of the incidents of rape alleged in Kunarac it was contended by the defense that because the victim, coded Witness DB, appeared to consent, Kunarac had not committed rape. ${ }^{74}$ Evidence was presented that because DB had taken an active role in the incident, by removing the accused's pants and kissing him, the act was consensual. ${ }^{75}$ However, the Trial Chamber found that the victim had complied out of fear - she had been threatened by a subordinate of the accused. ${ }^{76}$ The Trial Chamber also noted that because the victim was detained, the accused could not believe that she had consented to the sexual intercourse. ${ }^{77}$ This is a similar view to that of many U.S. jurisdictions - that those in confinement are incapable of consenting to sexual acts with those who guard them. However, the ICTY Trial Chamber approaches this issue from the opposite side, and it is an important distinction to make. The ICTY places the onus on the perpetrator in determining whether they believed the victim consented. The ICTY found that there is no way a person holding power over a detainee could believe that the detainee consented to a sexual act. In this distinction, the ICTY suggests that perceived consent on the part of the perpetrator may negate guilt, however, the Trial Chamber reaches the same end as the majority of U.S. jurisdictions do via statute, that a person detained cannot consent to a sexual act with the detainer.

In a similar finding, the Trial Chamber rejects the defense by Kovac that witness FWS-87 was in love with him and therefore consented to sexual acts. The Trial Chamber found that the relationship between the de-

whenever women in confinement are raped at the hands of those who confine them, it must be seen as torture, regardless of the reason for their confinement.

74 Prosecuter v. Kunarac et al, Trial Chamber Judgment, IT-9623-T \& IT-96-23/1-T, February 22,2001, ICTY. At $19644-646$.

75 Id.

76 Id.

77 Id 
tainee and Kovac was one of "cruel opportunism, of constant abuse, and domination." ${ }^{, 78}$ In the U.S. there are instances in which female prisoners and their guards develop "relationships", but there still exists a legal presumption that a person who is imprisoned is incapable of consenting to those that wield power over them. ${ }^{79}$ Whether or not there appears to be a consensual relationship is irrelevant in these instances, the women's status as a prisoner makes them incapable of consent, and the same appears to be true within the ICTY jurisprudence.

The Kunarac Trial Chamber decision was appealed following the conviction of each of the accused. ${ }^{80}$ While the Appeals Chamber upheld the convictions and sentences imposed by the Trial Chamber, they gave additional commentary on the crime of rape as torture. The Appeals Chamber agreed with the Trial Chamber's analysis of international jurisprudence, arriving at the conclusion that rape may constitute torture. ${ }^{81}$ The Appeals Chamber described the conditions to which the women were subjected: the rapes occurred in detention centers, against women who were considered the sexual prey of their captors, and that any who resisted were treated with extra brutality, and noted that the repeated nature of the rapes also indicated torture. ${ }^{82}$ Finally, the Appeal Chamber rejected the argument that the rapes were based entirely on the sexual satisfaction of the perpetrators and not for any prohibited purpose defined by the crime of torture. ${ }^{83}$ The factors that led the Appeals Chamber to uphold the convictions exist in instances of prison rape in the U.S. Particularly included is the characterization of the women as the captive sexual prey of officers, the retaliations for resistance and the conclusion that repeated instances of rape indicates torture. These factors are seen in many of the studies on U.S. Prison rape outlined earlier.

While the conditions that lead to the imprisonment of the women in the Kunarac case are quite different than those that lead to imprisonment in the U.S., the condi-

$78 \quad$ Id at $\$ 762$.

79 M. Dyan McGuire.

80 The Trial Chamber issued the following sentences: Kunarac 28 years imprisonment, Kovac 20 years imprisonment, Vukovic 12 years imprisonment. Each of these sentences was upheld by the Appeals Chamber. Kunarac et al Appeals Chamber Judgment, ICTY, June 12, 2002.

81 Id. at 9 \181-185.

82 Id at 9 १ 326-334.

83 Id at 180. tions that they suffer once confined share many similarities that have proved key to torture convictions. The women in the detention centers at Foča High School, Partizan, and the brothel at Karaman's House who were victims of rape at the hands of those who held them in custody experienced similar abuses as women imprisoned in the U.S. who are victims of rape at the hands of those who hold them. While their imprisonment is the result of drastically different circumstances, the abuse these women suffer as well as the short and long-term effects are the same. Both scenarios include threats against the women themselves, as well as their families. Both sets of victims experience physical and mental harm that is lasting and undeserved.

\section{Conclusions and Recommendations}

Rape within a government run detention facility, in the U.S. or abroad, is an act of torture. Government institutionalized torture is a particularly heinous crime because it sends the message to society that these crimes will go unpunished, that the victims are unworthy of protection, and that perhaps these women deserve it. While the attitudes of society regarding female prisoners in the U.S. are not clear through testimony or data, they are gleaned through the laws and barriers those laws create. It is clear that while the international community views rape in detention as torture, the U.S. is rife with barriers to justice for those victims. Although the 8th amendment provides prisoners protection against the actions of guards as well as other prisoners, PLRA attempts to reduce frivolous lawsuits and ultimately acts as a barrier to relief for rape victims. In addition to these legal barriers, women are often reluctant to go through the process out of shame and a fear of reliving the experience, and when they do come forward, prosecutors view these cases as high risk/low reward, creating another barrier/layer of complexity. These legal barriers indicate an unspoken belief that female prisoners are somewhat deserving of this punishment. There is no international consensus regarding a definition of rape, but some definitions have found that rape can and has been used as torture. The international examples used in this article reveal that while conditions of imprisonment are radically different, the abuse these women suffer are essentially the same. When compared to the justice for rape victims actively sought at the ICTY, the 
similarities of the circumstance, and the differences in the perception of the victims, contribute to this theory. Absent any clear effort, up until this point, to end the government impunity, it can be assumed that as a whole society is indifferent towards victims of prison rape. Because victims of rape in armed conflict are given mechanisms to seek justice, it can be assumed that it is not an overall indifference toward rape victims, but rather towards criminal rape victims. The key difference, as discussed in this article while acknowledge many undiscussed differences, is that the victims in armed conflict are confined unjustly by their rapists, while the victi$\mathrm{ms}$ in U.S. prisons are confined as a result of the U.S. justice system. Being labeled a criminal, however, does not allow for rape/torture. The very existence of the various torture conventions confirms that conclusion.

While there are many layers of difficulty in obtaining justice for prison rape victims, there is a substantial movement being made with the PREA. PREA is indicative of a cultural shift towards ending torture with impunity in the U.S. prison system. Its an acknowledgement of a widespread and systemic problem. While it may not be enough to seriously combat these extreme human rights violations, it is certainly a step and hopefully an indication of more concrete and effective steps to come. Hopefully, when faced with the data collected through the regulations, the U.S. will begin to take more active steps towards ending this gross human rights violation that exists throughout the country. If the BJS can begin to develop a stronger picture of the level of rape in U.S. prisons, and that data is effectively used to sanction facilities in violation of the regulations, there will be a strong and historic shift in the issue of torture and impunity within the U.S. prison system. With that shift, hopefully, prosecution will grow. Prosecutors should look to the trend towards ending prison rape and begin to take an active role in leading the U.S. out of its shameful position as a country that routinely submits its citizens to a very damaging torture, and does so without justice. The advancements in international criminal prosecutions can only support domestic prosecutorial efforts. While not controlling by any means, the decisions of international courts give domestic courts greater jurisprudence to draw from. While women in the Former Yugoslavia were raped and tortured based only on their heritage, women in the U.S. suffer the same fate, based only on their status as prisoner. Regardless of the offense that has brought these women to be imprisoned, it does not justify this cruel and degrading treatment. They are no less deserving of protection than their counterparts across the globe imprisoned because of their status in a community. The Muslim women were seen as unrapeable as well, they were seen as criminals to society as well, and they receive justice because the government who imprisoned them has gone. Governments cannot continue to torture with impunity because they are in power, and the women in U.S. prisons deserve the protection of their government from the violence of their captors. 
Para publicar na Revista de Direito Internacional, acesse o endereço eletrônico www.rdi.uniceub.br ou www.brazilianjournal.org.

Observe as normas de publicação, para facilitar e agilizar o trabalho de edição. 